\section{A \\ ox}

\section{THE DEBILITATED CHILD.*}

\section{BY}

\section{WILFRED VINING, M.D., F.R.C.P.,}

PROFESSOR OF CHILDREN'S DISEASES, LEEDS UNIVERSITY; PHYSICIAN TO THE CHILDREN'S DEPARTMENT, GENERAL. LNFLRMARY, LEEDS.

We are living at a time when prevention of disease and the recognition of its earliest signs are being called for in no uncertain voice, and those of us who are specially engaged in work amongst children realize only too well the difficulties met with in the understanding and interpretation of defects in health at an age periud when one. would expect the problem to be in its simplest form.

The system in vogue in this country, while it offers liberty of the subject and free choice of doctor, has the disadvantage that it leaves the decision as to. whether the child needs medical attention to the parent rather than to the expert. No doubt the development of the school medical service will do a great deal to remedy this. Many abnormalities which we, as experts, recognize as evidenco of health defect, possibly of a serious nature, are looked upon by parents as part of the natural development of the child. Pains in the legs are growing pains, nervous conditions are due to worms, refusal to gain weight proves that the child is wiry and following in his father's footsteps, or the child's $\mathrm{C} 3$ condition is accepted as evidence of a delicate constitution inherited from tho mother's side.

$I$ have met with some twenty children with established acquired heart disease who had not at any time been under medical treatment. In none of these children had there been a history of chorea or joint rheumatism, and in five of them the most detailed inquiry failed to elicit from the parent evidence of any health disturbance whatsoever. Personally I refuse to believe that a child can acquire valvular disease without there having been some degree of health disturbance during its development. As ono who has worked in a large out-patient department for some fifteen years, during eight of which my patients have been children, nothing has impressed mo more than the large number of children who are brought with health defects which are accompanied by no gross physical signs, yet whose disabilities are more or less serious, frequently chronic, and most baffling in their refusal to respond to any treatment we can offer in hospital practice.

I have deliberately chosen the title "The debilitated child" in order to allow myself freedom to discuss the subject from any point of view. I prefer not to use the word "delicate" because this infers congenital weakness. While a certain minority of these children are undoubtedly the victims of a bad start in life, I am convinced that the majority acquire ill health for rcasons and from causes which I propose to touch upon in this lecture.

The debilitated child is brought to us for many reasons, and his health abnormalities can be viewed from different angles. The majority of these children are found among the hospital class, though by no means an inconsiderable minority are found amongst the children of the well-to-do. I am going to deal with the age period 3 to 12 years-most of the cases range between 5 and 10 years-and I can best deveiop my subject by giving a list of the symptoms presented by these children and noticed during periods of observation varying from a few months to several vears.

The first perfectly just criticism will bo that $I$ am bunching together a number of entirely different conditicns. My answer is that I am merely stating the actual symptoms of a large group of children whose histories repeat themselves with monotonous frequency, and whose appearance, behaviour, and physical condition seem to inclicate that they have some features in common which

* Abstract of a British Medical Association Lecture delivered to Darlington Division. make it desirable that they should be studied, at least in the first instance, as a group. Can we make any kind of order out of this seeming confusion?

Analysis of the Symptoms of the Debilitated Child. Numerical frequency of symptoms presented by (A) 300 debilitated children, compared with relative frequency of the symptoms in four arbitrary subgroups-namely: (B) 121 toxic debility or rheumatic type cases, (C) 61 supposed tuberculous- cases, (D) 55 cases of "chronio intestinal dyspepsia," and (E) 63 "nervous" children.

\begin{tabular}{|c|c|c|c|c|c|c|c|c|}
\hline & & & & A. & B. & c. & D. & E. \\
\hline Nervousness & ... & $\ldots$ & ... & 203 & 68 & 38 & 39 & 63 \\
\hline Loss of appetite & $\ldots$ & ... & $\ldots$ & $2 \div 7$ & 86 & 44 & 48 & 42 \\
\hline Wasting or " no g & ain" & $\ldots$ & $\ldots$ & $2 \mathrm{C3}$ & 74 & $47^{\circ}$ & 37 & 45 \\
\hline Tired feelings & ... & ... & $\ldots$ & 164 & 67 & 38 & 30 & 29 \\
\hline Pallor oi "faints " & & $\ldots$ & .. & 152 & 54 & 30 & 33 & 35 \\
\hline Disturbed sleep & ... & ... & $\ldots$ & 147 & 60 & 24 & 26 & 37 \\
\hline Constipation & ... & ... & ... & 145 & 56 & 26 & $3 i$ & 29 \\
\hline Limb pains ... & $\ldots$ & ... & ... & 120 & $E 8$ & 23 & $23^{\circ}$ & 29 \\
\hline Headaches $\quad .$. & ... & $\ldots$ & $\ldots$ & 107 & .49 & 20 & 18 & 20 \\
\hline Thread worms & $\ldots$ & ... & $\ldots$ & 97 & 29 & 20 & 29 & 19 \\
\hline Abdominal pain & $\ldots$ & ... & $\ldots$ & 91 & 32 & 15 & 25 & 19 \\
\hline Habit spasm & ... & $\ldots$ & $\ldots$ & $! 9$ & 16 & 5 & 7 & 31 \\
\hline Bilious attacks & $\ldots$ & $\ldots$ & $\ldots$ & 51 & 22 & 7 & 15 & 7 \\
\hline "Swcating" & $\ldots$ & $\ldots$ & $\ldots$ & 50 & ij & 22 & 9 & 9 \\
\hline Nocturnal enures & & $\ldots$ & $\ldots$ & 48 & 9 & 7 & 9 & 21 \\
\hline Sore throats & ... & ... & $\ldots$ & 41 & 27 & 6 & .3 & 5 \\
\hline "'Swollen glands' & & $\ldots$ & ... & 37 & 21 & 6 & .5 & E \\
\hline Loose stools ... & $\cdots$ & $\ldots$ & $\ldots$ & 33 & 7 & 7 & 12 & 7 \\
\hline Latent chorea & $\ldots$ & $\ldots$ & $\ldots$ & 29 & 13 & 2 & 0 & 12 \\
\hline Pain in the side & $\ldots$ & $\ldots$ & ... & 28 & 12 & 8 & 5 & 3 \\
\hline Depraved appetit & & $\ldots$ & $\ldots$ & 21 & 8 & 5 & 5 & 3 \\
\hline
\end{tabular}

Without for the moment committing ourselves to an opinion as to the production of these symptoms, we can at least view them as belonging to three main groups: (1) those related to the digestive system and intestinal tract, in which group wo would place abdominal pain, constipation, and loss of appetite; (2) those suggesting tho presence of a toxaemia-for example, aching limbs, tired feelings, listlessness, and headaches; and (3) those related to disturbances of the nervous structures-namely, nervous irritability, fidgety states, habit spasm, disturbed slcep), nocturnal enuresis, and nervous unrest generally. The children. frequently seem to classify themselves in this way, certain symptoms being so prominent that we label this child as an example of chronic intestinal dyspepsia (or, as Reginald Miller. has designated him, the "intestinal child"); another child, with aching limbs, tired feelings, and want of energy, pointing to the presence of toxaemia, wo may label as "toxic debility" or the "rhoumatic type"; while a third child wo may label "nervous" because of the prominence of the nervous manifestations. The symptoms of another child may suggest the possibility of tubercle, in that wasting, cough, catarrhal bronchial tubes, and sweating are promiinent in the history obtained from the parent. I want, however, to make it quite clear that any such grouping of sysuptoms and children is arbitrarr, and is carried out merely to call attention to certain types which present themselves at the clinic. Too much pigeon-holing and classification may lead to failure to appreciate the main underlying defects. We find that nervousness of some degree is common to all groups, that loss of appetite is found as frequently in other groups as it is in the child classificd as "intestinal," and that constipation, loss of weight, and sweating are to be found distributed among all types. In order to show this I have compared the four subgroups with the main group as a whole.

The clinical examination also meals certain physical characteristics which are more or less common to all tho [3561] 
groups. The dhildren are underweight, pale; sometimes sallow, and many have dark rings mider their eyes. They are usually filgety, and some show habit spasm, and generally they give the impression of being timid and apprehensive. Their nuscular systems are toncless and poorly developed, and this tends to produce stooping and gencral "flop," which results in an exaggeration of the natural curves of the spine and prominence of the abdomen. In a proportion of the children the abdomen actually is slightly distended. The glands in both triangles of the neck are more easily felt than in a healthy chidd, and this is specially true of the glands of the posterior triangles. This is not merely a local enlargement, as the axillary glanes are nearly always felt to a degree unusual in the healthy child, and sometimes the hyperplasia is very evident. The tonsils are frequently enlarged and sometimes unhealthy in appearance; evidence of adenoids is not uncommon. Needless to say, the degree of physical defect varies firom case to ease, and in many the degree of physical debility has not reached a stage reeognizable by the parent, who may assure us that the child was perfectly well until a week or two previonsly, when a particular symptom manifested itself.

\section{The Explanation of the Symptoms.}

What explanation ean be offered for these symptoms? In discussing this I must refer to the subject of diathesis, which has been revived during recent years. The expressions lymphatic, exudative, nervous, rhenmatic, and tuberculous have been used from time to time. I doubt whether they have done more than to make confusion worse confounded.

Dr. H. C. Cameron ${ }^{2}$ has suggested the dirision of children into two main groups-namoly, the exudative diathesis group, which includes the old scrofula type, and the neuro-arthritic group. Ho believes that the two types aro the result of inherited constitutional peculiarities which make the child react diffeiently to abnormalities of his environment. Cameron regards catarhal affections generally, glandular enlargements, and the temeleney to rheumatic and tuberculous affections as characteristic of the former group, and nervous upsets, eyclical vomiting, vasomotor disturbances, and lack of energy as characteristic of the latter group. My own fecling is that the insistence upon a diathesis as an explanation for the way in which the child responds to infection and environmental stimuli is not without value in some cases, but I doubt whether it is possible in the majority of children to make any such differentiation. I fancy it is better to accept each case on its merits rather than endeavour to judge it in the light of a preconceived theory of diathesis, although it must be confessed that Cameron's " nervous child," with his special liability to metabolic upsets, is very true to life.

\section{The Nervous Chilut.}

Though no one explanation adequately cover's all cases, certain facts and probabilities may be admitted. Nervousness is of two main types. There is the unvestrained and more pasitive type, in which the nervousness is more active and insistent; the children of this type are highly strung, emotional, restless, and mentally alert, though laeking the ability to concentrate; they are specially prone to habit spasm, so-called latent chorea described by Reginald Miller, ${ }^{3}$ tired feelings, aching limbs, nocturnal enuresis, bilious attacks, and headaches. In the second and, in my opinion, more common type the child is characterized by irritability of temper, fretfulness, and timidity. I would, however, again emphasize the point that there is no clear line of distinction, the majority of onr cases presenting nervous symptoms in all kinds of groupings and in combination with other ahnormalities in a way that makes it hopeless to attempt classification. There is, however, no doubt that only in a minority of these children is there an inherited nervous instability, but while symptoms such as habit spasm, bed-wetting, and nixht terrors may occur in children who by no stretch of the imagination could be called debilitated, it is when the child with the inherited instability become debilitated that these nervous symptoms are acutely developed. But taking nervousness generally, I would say that the large majority of nervous children acquire their nervous instability during life, and that it is anong debilitated children that the majority of the nerrous cases are to be found.

The Couses of Acquired Nervous Instability.

While agreeing that the enviromment, in which are inchiled parental care, bad hygiene, and exeessive mental and physical stinmlation, will accentuate the condition, it is my heliof that the two ehief factors producing nervousness are chronic toxacmias and deficiencies in the diet. The -deficiency is usually not in total calories-these children are not starred children in the true sense of the word-but a relative deficiency in one or more essential constituents, which, acting over a prolonged period, gradually brings ahont debility and damage of the delicate nervous structures of the growing child. It have myseif pointed ont that many of the symptoms of these debilitated children can be legitimately gronped under the heading of rheumatic toxaenia. All authorities are agreed that nervous instability forms an important part of the rheumatic picture, and the question at issue would therefore appear to be this: Is the nervons instahility eviclence of an inherited diathesis favourable to the dovelopment of the rheumatic affection, or of an acquired health defect which may precerle by months or years the full developmont of rheumatism?

The presence of toxaemia is diffeult to prove or disprove, but it is not unreasonable to believe that many of these nervous phenomena are cansed by toxic irritation. The toxic state may be bacterial or metabolic in origin. Cameron, ${ }^{5}$ and recently Osman, ${ }^{6}$ have snggested that the canse of many of the nervaus phenomena is an acidosis or ketosis, and recommend as treatment the free use of sugar and the reduction of fat in the diet. We find acidosis not infrequently amongst children whose parents are endeavouring to ensure against tuberculosis by forcing on them milk foods and cream, and acidosis may also occur in the child whose diet does not contain excess of fat, the explanation then being that the child possesses an inherited unstable metabolism and a nervous system which are easily influenced by envirommental and toxaemic stimuli.

My criticism of this explanation would be this: While agreeing that the immediate states of acidosis can be met by increasing the sugai ration, I would hesitate to believe that the prevention and cure of the debilitated. state and its acidosis exists in the flee use of easily assimilated carbohydrate. In the first place, the majority of these children get little but carbohydrate. Though their diet may be shor't in total calories it is certainly not relatively short in carbuhydrate. calories. A starvation diet may result in acidosis, and the child with a lost appetite may get his acidosis in this way, but this is merely a vicions circle which may be broken temporarily by the addition of sugar. The prevention and cure of the underlying condition which has lecl to the formation of the vicious circle is a very different problem. In the second place, acidosis is far more frequently the result of a toxaenia than it is a primary condition, and if we concentrate our attention upon the acidosis we may miss its underlying cause. I have no doubt that Dr. Cameron and Dr. Osman would be the last to insist that carbohydrate is the most important constituent of the child's diet, and any criticism I have put forward is offered rather to emphasize the importance of other constituents of the diet, specially of the protein, which of late have been relegated to a less important position than they deserve.

The throat and the alimentary traet suggest themseives as the two important points from which toxaemias may arise. The time has not yet come to define accurately the relationsinip of unhealthy conditions of the nasopharynx to the debilitated state; it will require a wide staistienl survey over a considerable number of years before the final vertict can be given. The problem is, however, of such importance that $I$ am bourd to consider it.

Abnormalities of the nasopharynx are not coifind to children of the hospital class, but I know of no figures 
which give the relative incidence between one class and another. Such statistics would possibly help in deciding the factors at work causing enlargement of tonsils and adenoids. There are many who would estimate the importance of the abnormalities of the nasopharynx in this way. Fnlargement of tonsils and adenoids is common to all classes. The cause of tise enlargement is repeated infections, to which all are prone. Among those children who are also debilitated or whose environment is defective such reaction to infection is likely to result in a greater degree of unhealthiness of the nasopharynx, and it is likely that absorption of organisms and their toxins will take place more readily. Hence the more frequent development of symptoms due to septic absorption amongst these children. It has been stated that the reason why Eton boys are free from rheumatic infection is because 70 per cent. of them have had their tonsils and adenoids removed before joining the school. During 1922 Kaiser $^{7}$ reported from America the result of the operation upon the weights of a series of 1,200 children between the ages of 3 and 15 years. $\mathrm{He}$ writes :

"They were all urgent cases and presented themselves for operation because of throat symptoms, and not because of malnutrition. As compared with similar children 7 per cent. were overweight, 59 per cent. were of average weight, and 34 per cent. were underweight. After periods of six to nine months the percentages of these three weight groups were changed so that 50 per cent. of the underweight group had attained normal weight."

Obviously diseased tonsils and adenoids do not necessarily impair nutrition, but the improvement in the underweight group after their removal suggests that they may do so. Recently: Paterson and $\mathbf{B r a y}^{8}$ in this country have shown that in selected cases removal of nasopharyngeal infection was followed by increase of weight and the clearing up of numerous constitutional symptoms, apart from any improvement in the local condition.

I would, however, remind you that there are other sides of the problem which require to be set off against these findings and opinions. In the first place, the numerous disturbances and symptoms which may appear in conjunction with the unhealthy nasopharyux do frequently occur in children whose throats show no abnormalities and whose glands at the angle of the jaw are not enlarged. The rheumatic affection, including heart lesions, occurs in rhildren whose throats have been thoroughly cleared. It is not uncommon to find that certain svmptoms, such as enuresis or bilious attacks, cease immediately after the operation, only to recur again after some montlis. This is in keeping with the peculiar way in which these symptoms will occur for a time in connexion with all kinds of psychological stimuli, and certainly one could instance cases in which enuresis started for the first time after the operation; indeed, I need hardly remind you that this operation performed upon a nervous child sometimes accentuates the nervous condition in a most distressing way. I would also point to the frequency with which aural discharge follows the operation and to the by no means infrequent development of enlargement of the cervical glands duiring the months or years which follow. These unfortunate happenings, and the fact that acute rheumatism, and especially chorea, occasionally follow in the wake of the operation, may, of course, be attributed to the stirring up of a germ nest, with resulting dissemination into the local structures or the system generally, and it could be said that the eradication of the germ nest was the lesser of two evils, notwithstanding the results which followed. But here again it should be mentioned that acute rhenmatic chorea, which all agree is a streptococcal encephalitis, may undoubtedly follow a shock of any trpe.

J. H. P. Paton' has recently compared childien who have had the operation performed with children who have not. Both groups of children belong to the professional ánd well-to-do class aud are pupils attending a large bparding school. He writes:

"It is evident that those subjected to the operation were not only no better than the rest, but were actually worse in practically every particular with the exception of entarged cervical glands."
My own personal impressions have been that when the local condition of the throat is obviously unhealthy and the nasopharynx is obstructed, the operation, besiles remedying the local condition, does undoubtedly produce good and often striking results in the child's gencral health. These results, however, are often only temporary, and the symptoms not infrequently return after. a few months. I have also seen children whose debilitated state seems to date from the removal of their tonsils and adenoids, and a recent review of cases has increased my belief that the routine removal of the tonsils and adenoids of debilitated children is a mistake and should only be molertaken after a thorough review of the child's condition. I have figures which refer to 100 children who have had their tonsils and adenoids removed and 200 children who have not; botli groups belong to the poorer classes of the community, and all of them come wnder the broad classification of debilitated children. These children have been watched for periods ranging from six months to three years, and the figures relating to the tonsillectomized group only deal with the post-operation period. I find that for each six months period the "no operation" group shows an average greater gain of weight than the "operation" group.

Of the 100 tonsillectomized children 23 hail had the operation performed previous to their first attendance at my clinic, and in only 29 other cases was it possible to compare the weight gains before and after the, operation. In the six months after operation 12 showed a greater gain, 14 showed a lesser gain, and 3 showed an equal gain in weight. Comparing periods of twelve months before and after the opcration, 3 showed a groater gain in the year following operation, 7 showed a lesser gain, and 1 showed an equal gain.

A legitimate criticism of my figures would be that the children who reased to attend after operation would quite likely be those who had so improved in health that further attendance was deemed unnecessary by the parent. I can only say that in a small minority who were looked up and prevailed upon to return for examination the gain in weight did not encourage me to believe that failure to attend was duc to return of health. In my opinion the benefits derived from this operation liave somo relation to the chances of convalescence afterwards, to the type of home to which the child returns, to the state of the child's nutrition at the time, and, lastly, to the efficiency of the mother. This also may be said: anything short of complete enucleation is useless, and should be disconrager. The operation should not be undertaken in cases where the local condition does not warrant it merely on the off-chance that the child's health defect may be inrproved.

While discussing the influence of the toxamias the question of tuberculosis must be mentioned. Many of these children are labelled as tuberculous or pre-tuberculous. Some 50 per cent. of them give a positive skin reaction to tuberculin, but I am confident that their debility and their symptoms are not due to tuberculous disease. Watched over a period of years they do not behave like tuberculous cases, and they do not blossom out into frank cases of tuberculosis during adolescence: The age period I am dealing with is particularly free from mortality from tuberculosis, and while risking the criticism of dogmatism I would say that frank tuberculosis arising during adolescence is usually a fresh infection developed from contact with another individual with the disease.

It may very naturally be suggested that a local gland lesion might be sufficient to produce a debilitating influence and toxaemia. This $I$ would very much doubt, as in my experience purely local disease, when obviously piesent, does not produce either debility or the kind of srmptoms we have been discussing.

\section{Digestire Disturbances and Debitity.}

A proportion of ases of debility with symptoms referable to digestive processes could be classified at once as examples of so-called chronic drspepsia, and severe cases fall into line with the "mucous "disease", described by the late Dr. Eustace Smith. ${ }^{10}$ But among all these debilitated children constipation or loose stools-much more frequently the 
former-loss of appetite, abdominal pain, threadworms, and mucous discharge occur with considerable frequency, and it is only when theso symptoms show themselves prominently in the history and clinical picture that the condition is labelled "dyspepsia." The word " dyspepsia" is unsatisractory, as it implies local disturbance in the alimentary tract, and tends to direct our attention from the wider and more important basis upon which the debilitated state develops. I may instance in this comnexion the symptoms of threadworms. Few fidgety children escape being treated for worms, the reason being that parents have learnt to appreciate how frequently threadworns appear in the stools of such children. The parasites may occur temporarily in the excreta of healthy children, yet their continued presence is an indication of an underlying state of the bowel wall which makes it possible for the worm to establish itself. Exactly similar clinical states are seen in children whose stools are free from worms, but which contain large quantities of mucous material.

Wo are dealing, I believe, with a constitutional and nutritional disturbance in which all tho systems of the body are involved, but in which the alimentary tract and digestivo function are moro particularly implicated. There is an impairment of the defence mechanism, and a defect both in the secretion of the different digestive juices and in the absorbing powers of the bowel wall. If this view is accepted then, notwithstanding the assertion of the bacteriologist and the pathologist that microbic and toxic absorption from the intestinal tract is unlikely, it is not unreasonable to believe that many of these toxaemias arise within the digestive system.

It is this conception of the debilitated state which leads mo to suggest that we are dealing with a health defect which belongs to the group of deficiency diseases. Authority is always emphasizing the importance of a better diet for children, yet when the problems of subnutrition are investigated and discussed the importance of the diet is not always insisted upon to the same degree as tho other factors of tho environment.

This may be illustrated by tho results of a recent investigation undertaken on behalf of tho Medical Research Council ${ }^{11}$ to ascertain the relationship of defective growth and health of children to poverty, diet, and other environmental factors. Tho main conclusion arrived at is that tho chief factor determining growth and health is maternal efficiency, which, we might assume, would be correlated with good and bad fecding; yet the opinion expressed in the report was that the family dict does not explain discrepancies in nutrition and health between different groups of children. Furthermore, the statement is mado in the report that a diet containing 10 to 12 per cent. of protein is well balanced with regard to this essential constituent-a statement which seems to me seriously to impair the value of the conclusions finally arrived at.

A 10 to 12 per cent. protein ration is the recognized adult allowance, though even for an adult this may be insufficient if the source of the protein is largely vegetable. It is also likely that the adult members of tho family would consume relatively a greater amount of the availablo protein, especially of the animal type, leaving to the smaller members of the family an amount of protein far below their minimum requirements, together with that part of the household's food which has always been looked upon as safer and more suitable for small children-namely, the carbohydrate. Protein is indispensable and non-interchangeable. The problem of the adult and the child are entirely different, and all authorities agree that the younger the child the greater tho amount and proportion of protein needed for maintenance, repair, and growth. Holt and Fales ${ }^{2}$ say that tho averago adult requires approximately 0.45 gram of protein per lb. of weight, and suggest that it is reasonable to supposo that the child requires 0.45 to 0.68 gram per $1 \mathrm{~b}$. of weight for maintenance alone, and insist that moro is necessary for growth, and that for the child animal protein should be given in preference to vegetable. They quote Gillett, who collected information from the literaturo up to 1917 with reference to the intake of healthy children between 2 and 15 years, as stating the protein intake to be 1.5 to 1 gram per $\mathbf{l b}$. They also quote Gephart and Camerer, who give the amounts as 1.8 to 1 gram per lb. for children and adolescents.

The observations of Holt and Fales upon a series of healthy children over 1 year indicate that approximately 15 per cent. of the total calories taken are protein calories, and that two-thirds of the protein is of animal origin. They also noted that the younger and more active child took the larger proportion. Crozer Griffith ${ }^{13}$ states that 20 to 25 per cent. of diet should be protein and 50 per cent. of it should be of animal origin.

Corry Mann ${ }^{14}$ has recently compared the effects of adding certain foods to the basic diet of groups of boys living under identical conditions; his results show that the daily addition of a pint of milk causes greater increase in height and weight than the addition of other foods-for example, casein, butter, etc. Although adding casein instead of a pint of milk meant giving some 300 less calories, yet it appears to be inferred that the greater gain in height and weight when milk was given must be due to other constituents than the protein. Leighton and. Clarks ${ }^{15}$ have shown, however, that the gain in weight and height is much the same, whether whole or separated milk is given, and I suggest that this proves that it is the protein which is the inportant factor.

Hutchison ${ }^{16}$ warns us against the danger of protein underfeeding. He writes that habitual underfeeding with protein is more injurious than underfeeding with fat and carbohydrate, and leads to what he aptly calls threadhare tissues. I am satisfied that the majority of these children do not receive anything like the amount of protein necessary for maintenance, repair, and growth. That protein is not the only deficiency is likely. There is a considerable amount of availablo evidence suggesting that lack of vitamin $A$ is a factor in lowering resistance to infections (Green and Mellanby's ${ }^{17}$ work in this connexion is important), and I would mention the work of McCarrison ${ }^{18}$ in connexion with lack of vitamin B.

\section{Treatment.}

Prophylaxis should be our first consideration, and the future lies in that direction. The problem of the child's diet is bigger than medicine, but not until the medical profession clearly defines what that diet shall be and how it stands in relation to the child's health shall wo get authority to realize that diet stands higher than education and psychology in the full development of the child's mental and physical health. It is useless to expect improvement in health by means of throat operations, artificial sunlight, commercial concentrated vitamins, and psychological clinics, while at the same time the child's tissue cell is seriously handicapped by persistent underfeeding of essential food constituents.

Immediate symptoms may be relieved by sugar, alkalis, laxatives, malt preparations, sedatives, and so forth; convalescent treatment and holidays from home are temporarily useful; attention to the throats of properly selected cases may produce immediate improvement; but all these together cannot remove from our midst the debilitated child while the diet remains persistently unsatisfactory.

\section{REFERENCES.}

1 Miller, Reginald : British Medical Journat, March 10lh, 19:8, p. 283.

2 Cameron, H. C.: Diseases of Children, 1926, p. 91.

3 Miller, Reginald : Medical Diseases of Chill w. 1911, p. 165.

4 Vining, C. W. : Pre-rheumatic Child. Procendings Bath Conferener, 1928.

5 Cameron, H. C. : British Medical Journal, Fcbruary 2nd, 1929, p. 185.

- Osman : British Medical Journal, January 26th, 1929, p. 150

Thaiser: Amer. Journ. Dis. Chill., xxii, 1922, p. 139

8 Paterson and Bray : Lancet, November 24ti, 19є8, p. 1074.

- Paton, J. H. P. : Quart. Journ. Mel., October, 1928, p. 107.

${ }^{10}$ Smith, Eustace: Wasting Diseases of Children, 1887, p. 208.

11 Medical Rescarch Council, 1926 : Poverty, Nutrition, and Grouth.

12 Holt and Fales: Amer. Journ. Dis, Chill., 1921, xxii, p. 371.

13 Griffith, Crozer : Diseases of Infants and Children, vol. i, 1921, p. 174.

14 Mann, Corry: Diet of Boys of School Age, Medical Research Council, 926

13 Leighton and Clark : British Medical Journal, January 5th, 1929, p. 23.

${ }^{10}$ Hutchison, R. : Food and Principles of Dietetics, 1902, p. 23.

17 Green and Ifellanby : British Medical Journal, October 20th, 1928, p. 693.

18 McCarrison : Studies in Deficiency Discases, 1921, p. 65. 